\title{
PENGGUNAAN LKM BERBASIS MASALAH PADA OUTDOOR ACTIVITIES UNTUK MENINGKATKAN MULTIPLE INTELLIGENCES MAHASISWA
}

\author{
Lilis Lismaya ${ }^{1)}$ \\ ${ }^{1}$ Dosen Program Studi Pendidikan Biologi FKIP, Universitas Kuningan \\ Email: lilislismaya2017@gmail.com
}

APA Citation: Lismaya, L. (2018). Penggunaan LKM Berbasis Masalah Pada Outdoor Activities Untuk Meningkatkan Multiple Intelligences Mahasiswa. Quagga: Jurnal Pendidikan dan Biologi, 10(1), 71-78. doi: 10.25134/quagga.v10i01.874.

\begin{abstract}
Abstrak: Penelitian ini dilatarbelakangi oleh pembelajaran yang masih dilakukan di dalam kelas saja, mahasiswa merasa terkungkung dalam ruangan kelas demi mencapai tujuan pembelajaran, padahal proses pembelajaran diharapkan menekankan pada pemberian pengalaman langsung untuk mengembangkan kompetensi agar menjelajahi dan memahami alam sekitar secara ilmiah. Adapun tujuan dari penelitian ini adalah untuk menganalisis penggunaan LKM Berbasis Masalah pada Outdoor Activities terhadap Multiple Intelligences Mahasiswa. Dalam penelitian ini populasi yang diambil adalah seluruh mahasiswa tingkat 1biologi FKIP UNIKU tahun ajaran 2016-2017 sebanyak115 mahasiswa. Sedangkan sampel yang diambil secara purposive sampling adalah 1 kelas ekperimen berjumlah 28 mahasiswa. Adapun metode yang digunakan adalah weak experimental atau eksperimen lemah dengan desain penelitian The One-Group Pretest-Posttest Design. Data yang diperoleh dianalisis dengan menggunakan uji $t$, diperoleh hasil 0,000 lebih kecil dari 0,05. Dengan demikian HI diterima, artinya terdapat peningkatan Multiple Intelligences mahasiswa melalui penggunaan LKM berbasis masalah pada Outdoor Activities.
\end{abstract}

KataKunci :LKMBerbasis Masalah,Outdoor Activities, Multiple Intelligences.

\begin{abstract}
This research is motivated by learning that is still done in the classroom only, students feel confined in the classroom to achieve learning goals, even though the learning process is expected to emphasize giving direct experience to develop competencies in order to explore and understand the natural environment scientifically. The purpose of this study was to analyze the use of Problem Based MFIs in Outdoor Activities towards Multiple Student Intelligences. In this study the population taken was all biology level 1 students of the Faculty of Education and Culture UNIKU 2016-2017 academic year as many as 115 students. While the samples taken by purposive sampling are 1 experimental class totaling 28 students. The method used is weak experimental or weak experiment with research design The One-Group Pretest-Posttest Design. The data obtained were analyzed using the t test, obtained results of 0,000 smaller than 0.05 . Thus $\mathrm{H} 1$ is accepted, meaning that there is an increase in the Multiple Intelligences of students through the use of problem-based MFIs in Outdoor Activities. Keywords: Problem Based MFIs, Outdoor Activities, Multiple Intelligences.
\end{abstract}

\section{PENDAHULUAN}

Biologi berkaitan dengan cara mencari tahu tentang alam secara sistematis, biologi bukan hanya berisi penguasaan kumpulan pengetahuan yang berupa fakta-fakta, konsep-konsep, atau prinsip-prinsip saja tetapi juga merupakan suatu proses penemuan. Sehingga pembelajaran tidak harus dilakukan didalam kelas saja, mahasiswa tidak merasa terkungkung dalam ruangan saja demi mencapai tujuan pembelajaran, karena melalui pembelajaran biologi diharapkan dapat menjadi wahana bagi peserta didik untuk mempelajari diri sendiri dan alam sekitar, serta prospek penggunaan lebih lanjut dalam menerapkannya didalam kehidupan seharihari. Proses pembelajarannya menekankan pada pemberian pengalaman langsung untuk mengembangkan kompetensi agar menjelajahi dan memahami alam sekitar secara ilmiah. Pendidikan biologi diarahkan untuk inkuiri dan berbuat sehingga dapat membantu peserta didik untuk memperoleh pemahaman yang lebih mendalam tentang alam sekitar.

Pendidikan bukan hanya bagaimana cara untuk memperoleh pengetahuan, namun 
Quagga: Jurnal Pendidikan dan Biologi Volume 10, Nomor 1, Januari 2018

pendidikan merupakan upaya untuk meningkatkan pemahaman, sikapdan keterampilan serta perkembangan diri mahasiswa (Fadriwati, 2017). Kemampuan atau kompetensiini diharapkan dapat dicapai melalui berbagai proses pembelajaran disekolah. Salah satu proses pembelajaran yang dapat digunakan untuk mencapai kompetensi diatas adalah melalui Pembelajaran diluarkelas (Outdoor Activities).

Outdoor activities merupakan satu jalan bagaimana kita meningkatkan kapasitas belajar mahasiswa. Mahasiswa dapat belajar secara lebih mendalam melalui objek-objek yang dihadapi dari pada jika belajar didalam kelas yang memiliki banyak keterbatasan. Lebih lanjut, belajar di luar kelas dapat menolong mahasiswa untuk mengaplikasikan pengetahuan yang dimiliki. Selain itu, Outdoor activities lebih menantang bagi mahasiswa dan menjembatani antara teori di dalam buku dan kenyataan yang ada di lapangan. Kualitas pembelajaran dalam situasi yang nyata akan memberikan peningkatan kapasitas pencapaian belajar melalui objek yang dipelajari serta dapat membangun keterampilan sosial dan personal yang lebih baik. Outdoor activities dapat dilakukan kapanpun sesuai dengan rancangan program yanhg dibuat oleh dosen (Ernawati, 2017).

Namun, tentu penerapan outdoor activities ini harus mempunyai panduan atau pedoman mengenai hal-hal apa saja yang berkaitan dengan materi yang dipelajari agar mahasiswa tidak terlalu meluas dalam hal menjelaskan permasalahan yang dibahas. Panduan tersebut perlu disusun dalam sebuah LKM yang didalamnya disajikan beberapa permasalahan terkait materi yang dipelajari untuk membimbing kegiatan pembelajaran mahasiswa diluar kelas dan melatih keterampilan berpikir mahasiswa khususnya pada mata kuliah morfologi tumbuhan yang memang topik kajiannya mengenai tumbuhtumbuhan yang ada di alam.

Melalui penggunaan LKM berbasis masalah inilah diharapkan dapat membimbing kegiatan mahasiswa dalam pembelajaran diluar kelas, sehingga dapat mencapai tujuan akhirya itu meningkatnya
p-ISSN 1907-3089, e-ISSN 2651-5869

https://journal.uniku.ac.id/index.php/quagga

Multiple Intelligences (kecerdasan ganda) mahasiswa khususnya kecerdasan naturalis.

\section{METODOLOGI PENELITIAN}

Metode penelitian yang digunakan dalam penelitian ini adalah weak experimental atau eksperimen lemah dengan desain penelitian The One-Group Pretest-Posttest Design (Fraenkel, 2007). Dalam penelitian ini hanya menggunakan kelas eksperimen yang diberikan perlakuan untuk menilai pengaruh dari perlakuan tersebut, tanpa dibandingkan dengan kelas kontrol. Adapun rancangan desain penelitiannya sebagai berikut :

Tabel1. Desain Penelitian The One-Group

\begin{tabular}{ccc}
\multicolumn{3}{c}{ Pretest-Posttest Design } \\
\hline 0 & $\mathrm{X}$ & 0 \\
Pretest & Treatment & Posttest \\
\hline
\end{tabular}

Populasi dalam penelitian ini adalah seluruh mahasiswa program studi Pendidikan Biologi, Universitas Kuningan yang berjumlah 115 mahasiswa. Sampel yang digunakan dalam penelitian ini diambil secara purpossive sampling sebanyak 1 kelas yaitu tingkat 1 semester dua mahasiswa program studi pendidikan biologi FKIP Universitas Kuningan dengan jumlah 28 mahasiswa yaitu mahasiswa yang sedang menempuh mata kuliah Morfologi Tumbuhan.

Instrumen yang digunakan berupa testertulis berbentuk soal essay, yang memuat indikator untuk mengukur kecerdasan naturalis. Tes diberikan pada awal dan akhir pembelajaran. LKM berbasis masalah yang digunakan pada saat proses pembelajaran morfologi tumbuhan. Angket untuk respon mahasiswa terhadap pembelajaran Morfologi Tumbuhan melalui Outdoor activities. Melakukan pengolahan dan analisis data dengan uji statistik, kegiatan meliputi pemberian skor untuk pretest dan posttest, menghitung $N$-gain, analisis data menggunakan Software Statistical Package for Social Science (SPSS) for Windows versi 16.0.

\section{HASIL DAN PEMBAHASAN}

Hasil penelitian akan disajikan secara berurutan sebagai berikut (1) perbedaan hasil Multiple Intelligences mahasiswa antara tes 
Quagga: Jurnal Pendidikan dan Biologi Volume 10, Nomor 1, Januari 2018

awal dan tes akhir pada pembelajaran Morfologi Tumbuhan Melalui Outdoor Activities, (2) peningkatan multiple intellegencies mahasiswa melalui penggunaan LKM berbasis masalah pada outdoor activities, (3) respon mahasiswa terhadap penggunaan LKM berbasis masalah pada outdoor activities.

Instrument yang digunakan dalam penelitian ini adalah soal berbasis multiple intellegencies khususnya kecerdasan naturalis yang mencakup materi bentuk helaian daun dan pola percabangan batang. Sebelum digunakan pada penelitian soal diuji cobakan terlebih dahulu pada mahasiswa yang telah menempuh matakuliah morfologi tumbuhan. Hasil uji coba soal meliputi uji validitas dan reliabilitas. Hasil uji validitas dan reabilias intrumen dijabarkan dalam Tabel 2. berikut:

Tabel2. Hasil Uji Coba Validitas dan Reliabilitas

\begin{tabular}{|c|c|c|c|}
\hline No. & Uji Statistik & Nilai & Simpulan \\
\hline 1. & Uji Validitas & 0,653 & Tinggi \\
\hline 2. & $\begin{array}{c}\text { Uji } \\
\text { Reliabilitas }\end{array}$ & 0,672 & Tinggi \\
\hline
\end{tabular}

Hasil analisis uji coba yang meliputi uji validitas menunjukkan nilai 0,653 artinya bahwa seluruh soal multiple intellegencies mempunyai validitas tinggi. Hasil uji reliabilitas menunjukkan nilai 0,672 artinya bahwa secara keseluruhan soal multiple intellegenc mempunyai reliabilitas kategori tinggi. Berdasarkan hasil uji validitas dan reliabilitas tersebut maka dapat disimpulkan bahwa soal multiple intellegencies dapat digunakan sebagai instrumen pada penelitian selanjutnya.

Perbedaan hasil antara tes awal dan tes akhir pada pembelajaran Morfologi Tumbuhan Melalui Penggunaan LKM berbasis masalah pada Outdoor Activities

Untuk mengetahui bagaimana penggunaan LKM berbasis masalah pada Outdoor activities activities terhadap Kecerdasan Naturalis pada pembelajaran morfologi tumbuhan maka dilakukan pengujian terhadap hasil pretest dan posttest. Berikut ini pada Tabel 3disajikan hasil rata-rata pretest dan posttest kelas eksperimen.
p-ISSN 1907-3089, e-ISSN 2651-5869

https://journal.uniku.ac.id/index.php/quagga

Tabel 3. Hasil Rata-rata Pretest, Posttest dan Indeks Gain Kecerdasan Naturalis

\begin{tabular}{|c|c|c|c|c|}
\hline \multirow{2}{*}{ Kelas } & \multirow{2}{*}{$\begin{array}{c}\text { Jumlah } \\
\text { Mahasiswa }\end{array}$} & \multicolumn{3}{|c|}{ Kecerdasan Naturalis } \\
\cline { 3 - 5 } & $\begin{array}{c}\text { Rata-rata } \\
\text { Pretest }\end{array}$ & $\begin{array}{c}\text { Rata-rata } \\
\text { Posttes }\end{array}$ & $\begin{array}{c}\text { Indeks } \\
\text { Gain }\end{array}$ \\
\hline $\begin{array}{c}\text { KelasEksper } \\
\text { imen }\end{array}$ & 28 & 70,36 & 79,86 & 0,65 \\
\hline
\end{tabular}

Tabel 3. Menunjukkan rata-rata hasil pretes kelas eksperimen yaitu 70,36. Setelah dilakukan pembelajaran dengan menggunakan LKM berbasis masalah pada Outdoor activities kemudian diberikan posttest untuk melihat kecerdasan naturalis mahasiswa. Hasil posttest menunjukkan angka 79,86 dengan nilai maksimal 80. Hasil analisis kecerdasan naturalis mahasiswa berdasarkan nilai ratarata pretestt dan posttest dapat juga dilihat pada gambar1.

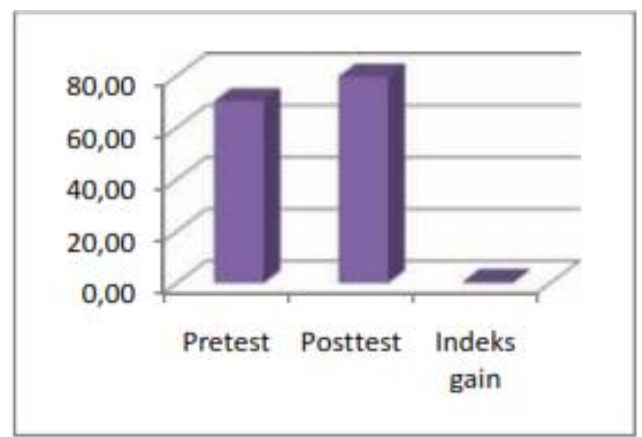

Gambar 1. Rata-rata Pretestt, Posttest, dan Indeks Gain

Selanjutnya dilakukan uji normalitas dan homogenitas terhadap pretesit dan posttest kecerdasan naturalis. Uji normalitas dan homogenitas digunakan sebagai prasyarat untuk uji statistik berikutnya. Hasil perhitungan uji normalitas data pretest, posttest dan indeks gain kecerdasan naturalis kelas eksperimen secara keseluruhan dapat Dilihat pada tabel 4.

Tabel 4. Hasil Uji Normalitas Kecerdasan Naturalis

\begin{tabular}{|c|c|c|c|c|}
\hline \multirow{2}{*}{ Data } & \multirow{2}{*}{ N } & \multicolumn{4}{|c|}{ Tes Kecerdasan Naturalis } \\
& & P-value & $\alpha$ & Kesimpulan \\
\hline Pre test & 28 & 0,45 & 0,05 & Normal \\
\hline Post test & 28 & 0,27 & 0,05 & Normal \\
\hline Indeks Gain & 28 & 0,16 & 0,05 & Normal \\
\hline
\end{tabular}


Quagga: Jurnal Pendidikan dan Biologi Volume 10, Nomor 1, Januari 2018

Hasil pengujian normalitas data dengan Kolmogorov-Smirnov diperoleh hasil skor pretestt berasal dari populasi yang terdistribusi normal dengan P-value 0,45 lebih besar dari $\alpha=0,05$. Demikian juga untuk skor posttest dan indeks gain memiliki Pvalue 0,27 dan 0,16 masing-masing memiliki nilai yang lebih besar dari $\alpha=0,05$ sehingga data berasal dari populasi yang terdistribusi normal.

Hasil Levene's Test uji homogenitas data pretest $\mathrm{t}$, posttest dan indeks gain kecerdasan naturalis mahasiswa menggunakan taraf signifikansi $\alpha=0,05$ dan diperoleh $\mathrm{P}$ - value seperti yang disajikan padaTabel 5 .

Tabel 5.Hasil Uji Homogenitas Skor Kecerdasan Naturalis

\begin{tabular}{|c|c|c|c|c|}
\hline \multirow{2}{*}{ Data } & \multirow{2}{*}{$\mathbf{N}$} & \multicolumn{3}{|c|}{ Tes Kecerdasan Naturalis } \\
\cline { 3 - 5 } & & P-value & $\boldsymbol{\alpha}$ & Simpulan \\
\hline Pretest & 28 & 0,47 & 0,05 & Normal \\
\hline Post test & 28 & 0,56 & 0,05 & Normal \\
\hline
\end{tabular}

Berdasarkan Tabel 5.diketahui bahwa skor pretestt dan posttest Kecerdasan Naturalis mahasiswa pada taraf signifikansi $\alpha=0,05$ memenuhi kriteria $\mathrm{P}$-value $\geq \alpha=0,05$, hal ini berarti bahwa varians data pretestt dan posttest adalah homogen.

Dari hasil pengujian statistik, data yang diperoleh berdistribusi normal dan homogen maka pengujian hipotesisnya dilakukan dengan uji statistik parametrik uji t Sample Independent Test. Uji $\mathrm{t}$ di lakukan untuk mengetahui tingkat signifikansi perbedaan kelas eksperimen dibandingkan dengan KKM matakuliah Morfologi Tumbuhan. Hasil pengujian dengan uji $\mathrm{t}$ kecerdasan naturalis selengkapnya dapat dilihat padaTabel 6 .

Tabel 6. Hasil Analisis Uji-t Kecerdasan Naturalis

\begin{tabular}{|c|c|c|c|c|c|c|}
\hline $\begin{array}{c}\text { Sumber } \\
\text { data }\end{array}$ & Kelas & $\begin{array}{c}\text { Skor } \\
\text { rerata }\end{array}$ & $\begin{array}{c}\text { Std. } \\
\text { Deviasi }\end{array}$ & Sign & $\alpha$ & Keputusan \\
\hline \multirow{2}{*}{ Post test } & Eksp & 79,86 & \multirow{2}{*}{4,07} & \multirow{2}{*}{0,00} & \multirow{2}{*}{0,05} & \multirow{2}{*}{ Terima $\mathbf{H}_{1}$} \\
\hline & KKM & 70 & & & & \\
\hline $\begin{array}{c}\begin{array}{c}\text { Indeks } \\
\text { gain }\end{array} \\
\end{array}$ & Eksp & 0,65 & 3,74 & 0,00 & 0,05 & Terima $\mathbf{H}_{1}$ \\
\hline
\end{tabular}

Berdasarkan Tabel 6. Dapat diketahui bahwa hasil uji t menunjukkan signifikansi $0,00<\alpha(\alpha=0,05)$, sehingga dapat disimpulkan bahwa terdapat perbedaan kecerdasan
p-ISSN 1907-3089, e-ISSN 2651-5869

https://journal.uniku.ac.id/index.php/quagga

naturalis yang signifikan kelas eksperimen dibandingkan dengan KKM matakuliah morfologi tumbuhan.

Berdasarkan hasil analisis kelas eksperimen secara keseluruhan pada uji $t$ menunjukkan terdapat perbedaan yang signifikan kecerdasan naturalis dibandingkan dengan KKM mata kuliah Morfologi Tumbuhan. Kedua hal tersebut menunjukkan bahwa terdapat pengaruh penggunaan LKM berbasis masalah pada pembelajaran morfologi tumbuhan melalui outdoor activities terhadap kecerdasan naturalis mahasiswa pada materi polapercabangan tumbuhan.

\section{Peningkatan Kecerdasan Naturalis Melalui Penggunaan LKM berbasis masalah pada Outdoor Activities}

Untuk mengetahui peningkatan hasil kecerdasan naturalis pada kelas eksperimen secara keseluruhan berdasarkan hasil Pretest dan Posttest maka dihitung dengan menggunakan rumus $\mathrm{N}$-gain lalu di klasifikasikan. Rekapitulasi hasil perhitungan $\mathrm{N}$-gain dijabarkan padatabel 4.6berikut ini:

Tabel 7.Hasil uji N-gain

\begin{tabular}{|c|c|c|}
\hline Kelas & Nilai & Kategori \\
\hline Eksperimen & 0,65 & Sedang \\
\hline
\end{tabular}

Dari tabel 7. Diatas dapat diketahui nilai $\mathrm{N}$-gain yang diperoleh pada kelas eksperimen secara keseluruhan adalah sebesar 0,65 berada pada kategori sedang, Artinya penggunaan LKM berbasis masalah pada Outdoor activities pada pembelajaran Morfologi Tumbuhan dapat meningkatkan kecerdasan naturalis mahasiswa sebesar 0,65dengan kategori sedang.

Selanjutnya dilakukan uji normalitas dan homogenitas terhadap nilai gain kecerdasan naturalis mahasiswa. Uji normalitas dan homogenitas digunakan sebagai prasyarat untuk uji statistik berikutnya. Hasil perhitungan uji normalitas nilai gain keterampilan memecahkan masalah kelas eksperimen secara keseluruhan ditampilkan dalam Tabel 8 . 
Quagga: Jurnal Pendidikan dan Biologi Volume 10, Nomor 1, Januari 2018

Tabel 8. Hasil Uji Normalitas Nilai Gain

\begin{tabular}{|c|c|c|c|}
\hline \multirow{2}{*}{ Data } & \multicolumn{3}{|c|}{ Tes Kecerdasan Naturalis } \\
\cline { 2 - 4 } & P-value & A & Simpulan \\
\hline N_Gain & 0,16 & 0,05 & Normal \\
\hline
\end{tabular}

Hasil pengujian normalitas data dengan Kolmogorov-Smirnov diperoleh hasil nilai gain kelas eksperimen berasal dari populasi yang terdistribusi normaldengan $\mathrm{P}$-value 0,16 lebih besardari $\alpha=0,05$. Hasil Levene's Test uji homogenitas nilai gain kecerdasan naturalis mahasiswa menggunakan taraf signifikansi $\alpha=0,05$ dan diperoleh P-value seperti yang disajikan padaTabel 9 .

Tabel 9. Hasil Uji Homogenitas Nilai Gain

\begin{tabular}{|c|c|c|c|c|}
\hline \multirow{2}{*}{ Data } & \multirow{2}{*}{$\mathbf{N}$} & \multicolumn{3}{|c|}{ Kecerdasan Naturalis } \\
\cline { 3 - 5 } & & P-value & $\mathbf{A}$ & Simpulan \\
\hline N_Gain & 28 & 0,25 & 0,05 & Homogen \\
\hline
\end{tabular}

Berdasarkan Tabel 9. Diketahui bahwa nilai gain Kecerdasan Naturalis mahasiswa pada taraf signifikansi $\alpha=0,05$ memenuhi kriteria P-value $\geq \alpha=0,05$, hal ini berarti bahwa varians data homogen.

Dari hasil pengujian statistik, data yang diperoleh berdistribusi normal dan homogen maka pengujian hipotesisnya dilakukan dengan uji statistik parametrik uji $\mathrm{t}$ Sample Independent Test. Uji $\mathrm{t}$ dilakukan untuk mengetahui tingkat signifikansi peningkatan kecerdasan naturalis mahasiswa, hasil uji $\mathrm{t}$ menunjukkan signifikansi $0,00<\alpha \quad(\alpha=0,05)$, sehingga dapat disimpulkan bahwa terjadi peningkatan kecerdasan naturalis mahasiswa setelah penggunaan LKM berbasis masalah pada Outdoor activities pada pembelajaran morfologi tumbuhan materi pola percabangan tumbuhan.

Kecerdasan naturalis yang diteliti dalam penelitian ini meliputi beberapa indikator, yaitu: a) mengklasifikasikan alam (Classifying Nature); b) melakukan investigasi (Hands- on Investigation); c) merawat alam (Caring for Nature) (Lazear, 2004). Adapun rekapitulasi hasil tes setiap indikator dari kecerdasan naturalis, meliputi 3 indikator yaitu : classifying nature (72,14), hands-oninvestigation $(70,36)$, dan caring for nature $(72,89)$, dengan nilai ratarata dari ketiga indikator tersebut mencapai 71,80 seperti disajikan pada tabel 10 .
p-ISSN 1907-3089, e-ISSN 2651-5869

https://journal.uniku.ac.id/index.php/quagga

Tabel 10. Rekapitulasi Indikator Kecerdasan Naturalis

\begin{tabular}{|l|c|c|c|c|}
\hline Indikator & $\begin{array}{c}\text { Classifying } \\
\text { nature }\end{array}$ & $\begin{array}{c}\text { Hands- } \\
\text { oninvestigatio } \\
n\end{array}$ & $\begin{array}{c}\text { Caringfor } \\
\text { nature }\end{array}$ & $\begin{array}{c}\text { Rata- } \\
\text { Rata }\end{array}$ \\
\cline { 1 - 4 } Persentase & 72,14 & 70,36 & 72,89 & \multirow{2}{*}{71,80} \\
\cline { 1 - 4 } Rata-rata & 7,21 & 7,04 & 7,09 & \\
\hline
\end{tabular}

Berdasarkan Tabel 10. Dapat dipahami bahwa ternyata melalui penggunaan LKM berbasis masalah pada Outdoor Activities ini terlihat kemampuan mahasiswa dalam mengklasifikasikan alam terutama jenis-jenis pola percabangan tumbuhan di Kebun Raya Kuningan mencapai prosentase $72,14 \%$ dengan nilai rata-rata 7,21 dan jika dibandingkan dengan KKM ternyata lebih besar dari KKM. Indikator berikutnya adalah Hands-on investigation mencapai nilai prosentase 70,36 dengan nilai rata-rata mencapai 7,04 dan nilai ini pun lebih besar dari KKM. Indikator selanjutnya yaitu Caring for nature mencapai nilai 72,89 dan rata-rata 7,09 lebih besar dari KKM. Setelah dihitung rata-rata dari ketiga indikator kecerdasan naturalis yang diteliti dalam penelitian ini mencapai 71,80 artinya jika kita bandingkan dengan KKM maka nilainya lebih besar dari KKM.

Dari hasil analisis prosentase tingkat ketuntasan belajar mahasiswa dapat dilihat bahwa sekitar 20 orang mahasiswa dari total 28 mahasiswa atau sekitar $71,43 \%$ sudah tuntas dalam belajar, sedangkan sisanya sebanyak 8 orang mahasiswa atau sekitar $28,57 \%$ mahasiswa belum tuntas dalam belajar. Artinya peningkatan kecerdasan naturalis ini masih dalam tingkat sedang sehingga masih ada beberapa mahasiswa yang belum tuntas dalam belajar walaupun sudah menggunakan LKM berbasis masalah.

Kecerdasan naturalis merupakan kecerdasanyang dimiliki oleh individu terhadap tumbuhan, hewan dan lingkungan alam sekitarnya. Individu yang memiliki kecerdasan naturalis yang tinggi akan mempunyai minat dan kecintaan yang tinggi terhadap tumbuhan, binatang alam semesta.Ia tidak akan sembarangan menebang pohon. Ia tidak akan sembarangan membunuh dan menyiksa binatang. Dania juga akan cenderung menjaga lingkungan di mana ia 
Quagga: Jurnal Pendidikan dan Biologi Volume 10, Nomor 1, Januari 2018

berada. Iaakan menyayangi tumbuhan, binatangdan lingkungan sebagaimanaia menyayangi dirinya sendiri. Inilah kecerdasan naturalis yangtinggi (Lazear, 2004).

\section{Respon Mahasiswa Terhadap Penggunaan LKM berbasis masalah padaOutdoor Activities}

Pada akhir pembelajaran diberikan angket kepada mahasiswa kelas eksperimen secara keseluruhan untuk mengetahui respon atau tanggapan mahasiswa terhadap penggunaan LKM berbasis masalah pada Outdoor activities pada pembelajaran morfologi tumbuhan. Angket yang dibuat meliputi 6 indikator yang kemudian dikembangkan menjadi beberapa pertanyaan.

Rekap persentase hasil tanggapan mahasiswa terhadap penggunaan LKM berbasis masalah pada Outdoor activities pada pembelajaran morfologi tumbuhan ditampilkan dalam Gambar 2.

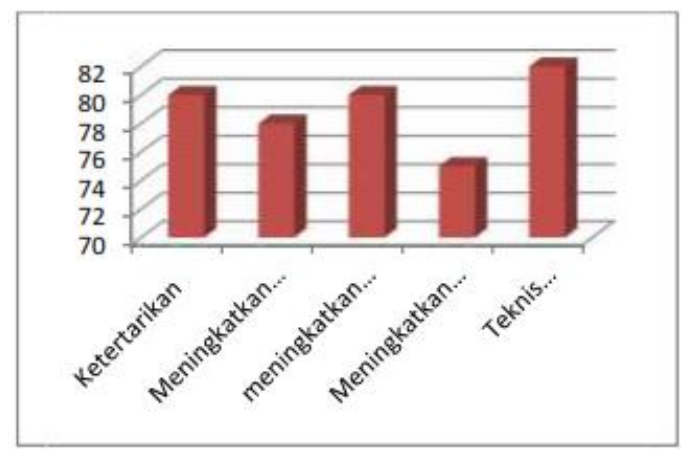

Gambar 2. Hasil Respon Mahasiswa Terhadap Penggunaan LKM berbasis masalah

Berdasarkan Gambar 2. dapat diketahui bahwa hampir seluruh indicator menunjukkan respon yang positif dari mahasiswa. Untuk indikator ketertarikan terhadap pembelajaran menunjukkan $80 \%$ mahasiswa yang menjawab iya dan $20 \%$ yang menjawab tidak, artinya sebagian besar mahasiswa merasa tertarik terhadap penggunaan LKM berbasis masalah pada Outdoor activities pada pembelajaran morfologi tumbuhan. Untuk indikator membantu mahasiswa dalam meningkatkan minat belajar, $78 \%$ mahasiswa menyatakan bahwa penggunaan LKM berbasis masalah pada Outdoor activities pada pembelajaran morfologi tumbuhan dapat membantu
p-ISSN 1907-3089, e-ISSN 2651-5869

https://journal.uniku.ac.id/index.php/quagga

meningkatkan minat belajar mereka. Untuk indikator meningkatkan Multiple Intellegencies menunjukkan $80 \%$ mahasiswa menyatakan bahwa penggunaan LKM berbasis masalah pada Outdoor activities pada pembelajaran morfologi tmbuhan dapat meningkatkan Multiple Intellegencies mahasiswa. Sedangkan untuk indikator meningkatkan kecerdasan naturalis menunjukkan $75 \%$ mahasiswa menyatakan bahwa penggunaan LKM berbasis masalah pada Outdoor activities pada pembelajaran morfologi tumbuhan dapat meningkatkan kecerdasan naturalis mereka. Indikator Teknis Pembelajaran Outdoor activities pada mata kuliah morfologi tumbuhan menunjukkan $82 \%$ mahasiswa menyatakan teknis pembelajaran outdoor activities menggunakan LKM berbasis masalah mudah dipahami. Sehingga dari keseluruhan respon mahasiswa dapat disimpulkan bahwa hampir seluruh mahasiswa memberikan respon yang positif terhadap penggunaan LKM berbasis masalah pada Outdoor activities pada pembelajaran morfologi tumbuhan.

\section{SIMPULAN DAN SARAN}

Berdasarkan hasil penelitian, diperoleh beberapa simpulan yaitu: 1) Terdapat perbedaan hasil antara tes awal dan tes akhir pada Multiple Intellegencies mahasiswa sebelum dan sesudah pembelajaran morfologi tumbuhan melalui penggunaan LKM berbasis masalah pada Outdor Activities. Hal ini ditunjukkan oleh hasil penghitungan rata-rata hasil Pretest, Posttest dan Indeks gain mahasiswa. Dengan demikian jelas terdapat perbedaan yang cukup signifikan antara hasil pretest dan posttest. Begitu juga ketika hasil posttest dibandingkan dengan KKM ternyata hasilnya lebih besar dari KKM. 2) Terdapat peningkatan Multiple Intellegencies mahasiswa terutama kecerdasan naturalisnya melalui penggunaan LKM berbasis masalah pada Outdoor Activities pada pembelajaran morfologi tumbuhan. 3) Respon positif dari mahasiswa terhadap penggunaan LKM berbasis masalah pada Outdoor Activites pada mata kuliah morfologi tumbuhan terhadap peningkatan Multiple Intellegencies mahasiswa. 
Quagga: Jurnal Pendidikan dan Biologi Volume 10, Nomor 1, Januari 2018

Berdasarkan hasil temuan dari penelitian, berikut ini merupakan beberapa saran guna melengkapi penelitian ini, diantaranya adalah : 1) Pada saat pembelajaran, diperlukan manajemen waktu yang baik antara tiap tahapan pada pembelajaran Outdoor Activities dan diakhir kegiatan perlu dilakukan penguatan konsep dan prinsip kegiatan dalam Outdoor Activities juga kecerdasan naturalis. 2) Pada saat menentukan tempat untuk pembelajaran hendaknya disesuaikan dengan materi pembelajaran yang akan dibahas agar tepat sasaran. 3) Pemilihan permasalahan yang digunakan dalam pembelajaran hendaknya permasalahan yang nyata ditemui dalam konteks kehidupan sehari-hari. 4) Respon positif siswa terhadap penggunaan LKM berbasis masalah pada Outdoor Activities pada konsep pola percabangan tumbuhan memberikan peluang penggunaan pembelajaran Outdoor Activities pada pembelajaran biologi konsep lain.5) Penelitian yang dilaksanakan oleh peneliti lain diperlukan sebagai masukan dalam penelitian ini. Hal ini karena adanya kemungkinan perbedaan pengetahuan, cara mengajar dan pengalaman akan mempengaruhi hasil penelitian.

\section{REFERENSI}

Anderson, L.W. \& D.R. Krathwohl. (2001). Kerangka Landasan Untuk Pembelajaran, Pengajaran Dan Asesmen Agung Prihantoro (penerjemah). Yogyakarta: Pustaka Pelajar.

Arends, R.I. (2008). Learning to Teach, seventh edition. Mc Graw-Hill Companies. New York.

Arikunto, S. (2007). Dasar-Dasar Evaluasi Pendidikan. Jakarta: Bumi Aksara.

Arikunto, S.(2008). Dasar-dasar Evaluasi Pendidikan. Edisi Revisi. Jakarta: Bumi Aksara.

Aunurrahman. (2009). Belajar Dan Pembelajaran. Bandung. Alfabeta.

Brookhart, S. (2010). How to Assess HigherOrder Thingking Skills In Your Classroom, Alexandria, Virginia. USA: ASCD.

DaharR. W. (1996). Teori-teori Belajar. Jakarta: Erlangga.
p-ISSN 1907-3089, e-ISSN 2651-5869

https://journal.uniku.ac.id/index.php/quagga

Ernawati, A. (2017). Pengembangan LKS Berbasis Multiple Intelligences Pada Pokok Bahasan Substansi Genetika. Makasar: UIN Alauddin.

Fadriwati, S. (2017). Pengembangan LKS Berbasis Multiple Intelligences pada materi Sistem Peredaran Darah pada Manusia. Batusangkar: IAIN.

Fraenkel, J. R \& Wallen, N. E. (2007). How to Design and Evaluate Researchin Education. San Francisco : Mc GrawHill Higer Education.

Hamzah, A. (2009). Teori Multiple Intelligences dan Implikasinya terhadap Pengelolaan Pembelajaran". Jurnal Tarbiyah Aqidah Usymuni Sumenep. 4, (2), 253-260.

Hernandez, J. V. (2010). "Multiple Intelligences as a New Paradigmin the Education of Mexico".International Journal of Education. 2, (1), 5-16.

Izzun. (2012). “Analisis LKS Biologi Karya MGMP SMP di kota Semarang yang digunakan siswa kelas VII semester gasal 2010/2011". Jurnal Phenomenon. 2, (1), 192-195.

King, Goodson\& Rohani. (2008). Higher Order Thingking Skills (Definition, Teaching strategies and Assesment). Educational Service Program.

Lazear, D. (2004). Higher-Order Thinking (The Multiple Intelligences Way). USA : Zephyr Press.

Mousavi, S. S., Ahmadi, F. (2013). "Education Effect Based on Gardner Multiple Intelligence Hypothesesin Students Mathematics Education Progressof High School Second Grade in Garmsar City". International Journal of Social Science (IJSS). 3, (1), 25-30.

Novak J. D dan Gowin D. B. (1984). Learning How to Learn. Cambridge: Cambridje University Press.

Rahmat, A. (2011). Petunjuk Praktikum Morfologi Tumbuhan. Bandung : Pendidikan Biologi FPMIPA IKIP Bandung.

Sibel., Ibrahim, A. (2013). "The Effect of Multiple Intelligence Theory Based Teachingon Student's Achievement and Retention of Knowledge (Example of The Enzymes Subject)". 
Quagga: Jurnal Pendidikan dan Biologi

Volume 10, Nomor 1, Januari 2018

International Journal on New Trends in Education and Their Implications.4, (3), 28-32.

Sugiyono. (2010). Metode Penelitian Pendidikan Pendekatan Kuantitatif, Kualitatif dan $R \& D$. Bandung: Alfabeta.

Tjitrosoepomo, G. (1988). Morfologi Tumbuhan. Yogyakarta: Gadjah Mada University Press.

Trianto. (2007). Model-model Pembelajaran Inovatif Berorientasi Konstruktivistik. Jakarta: Prestasi Pustaka.
p-ISSN 1907-3089, e-ISSN 2651-5869

https://journal.uniku.ac.id/index.php/quagga 